Jurnal Mengenai Dasar-Dasar Pemikiran Hukum: Filsafat dan IImu Hukum Tersedia online di https://ejournal2.undip.ac.id/index.php/crepido/

Volume 01, Nomor 01, Juli 2019

\title{
CAROK, 'DI PERSIMPANGAN’ BUDAYA DAN HUKUM POSITIF
}

\author{
Emy Handayani, Fatih Misbah \\ Fakultas Hukum Universitas Diponegoro \\ Jl. Prof. Soedarto, S.H., Tembalang, Semarang \\ emyfhundip@yahoo.co.id
}

\begin{abstract}
Carok culture as an attempt to resolve disputes in Madura using violencehas different meanings for the general public and Madurese society. For the people of Madura, carok is a recovery of self-esteem that associated with wealth, throne, and women. There is a phrase "Lakona daging bisa ejai', lokana ate tada' tmbana kajaba ngero' dara." The meaning of the phrase is "The wounded flesh can still be stitched, but if the wounded heart has no cure but drinking blood". Meanwhile, for the community, this act can not be justified because it is a vigilante act and contrary to applicable in criminal law. This study was conducted with the aim of knowing the values of carok culture and to know the extent to which Indonesian criminal law can accommodate the values of the carok culture.
\end{abstract}

Keywords: Carok Culture; Criminal Law; Dispute Resolution

\begin{abstract}
Abstrak
Budaya carok sebagai upaya penyelesaian sengketa di Madura yang menggunakan kekerasan memiliki arti yang berbeda bagi masyarakat umum dan masyarakat Madura. Bagi masyarakat Madura, carok merupakan pemulihan harga diri yang berhubungan dengan harta, tahta, dan wanita. Ada istilah 'Lakona daging bisa ejai', lokana ate tada' tmbana kajaba ngero' dara." Arti ungkapan tersebut adalah "Daging yang terluka masih bisa dijahit, tapi jika hati yang terluka tidak ada obatnya, kecuali minum darah." Sedangkan, bagi masyarakat umum, tindakan ini tidak bisa dibenarkan karena merupakan tindakan main hakim sendiri dan bertentangan dengan hukum pidana yang berlaku.Penelitian ini dilakukan dengan tujuan mengetahui nilai-nilai budaya carok dan sejauh mana hukum pidana Indonesia dapat mengakomodir nilai-nilai budaya carok tersebut.
\end{abstract}

Kata Kunci: Budaya Carok; Hukum Pidana; Penyelesaian Sengketa

\section{A. Pendahuluan}

Madura merupakan nama sebuah kepulauan yang berada di ujung Jawa Timur. Daerah ini mayoritas dihuni oleh kaum pribumi Madura. Masyarakat Madura dikenal memilliki budaya yang khas, unik, dan identitas budayanya itu dianggap sebagai jati diri individual maupun komunal etnik Madura dalam berperilaku dan berkehidupan. Salah satu budaya yang terkenal di Madura adalah carok. Carok dalam bahasa Kawi Kuno artinya perkelahian. Perkelahian tersebut biasanya melibatkan dua orang atau dua keluarga besar, bahkan sering terjadi perang antar penduduk desa di Bangkalan, Sampang, dan Pamekasan. Pemicu dari carok ini berupa perebutan kedudukan di keraton, perselingkuhan, rebutan tanah, bisa juga dendam turun- 
temurun selama bertahun-tahun. ${ }^{1}$ Intinya adalah demi kehormatan. Dalam ungkapan Madura, Lebbi Bagus Pote Tollang Atembang Pota Mata (lebih baik mati, daripada hidup menanggung malu)

Penelitian tentang budaya Carok menarik untuk diteliti karena tradisi Carok memiliki konotasi dan perspektif yang negatif bagi masyarakat luas. Carok diartikan sebagai pembunuhan sebagai upaya balas denam, akan tetapi Carok memiliki makna yang berbeda bagi masyarakat Madura karena berkaitan dengan pemulihan harga diri.

Carok merupakan salah satu alternatif penyelesaian sengketa pada masyarakat Madura. Penyelesaian tersebut merupakan penyelesaian dengan menggunakan jalur kekerasaan. Penyelesaian dengan jalan kekerasaan ini sering kali menutup kemungkinan penyelesaian sengketa secara damai. Dalam kaitan ini tampak bahwa sengketa masyarakat diakhiri dengan memunculkan sengketa yang lain. Penulis tertarik untuk mengungkap fenomena Carok sebagai salah satu upaya penyelesaian sengketa yang berbenturan dengan aturan Hukum Negara di Indonesia. Dalam realitasnya, perilaku dan pola kelompok etnik Madura tampak sering dikesankan atas dasar prasangka subjektif oleh orang luar Madura. Kesan demikian muncul dari suatu pencitraan yang tidak tepat, baik berkonotasi positif maupun negatif. Prasangka subjektif itulah yang seringkali melahirkan persepsi dan pola pandang yang keliru sehingga menimbulkan keputusan individual secara sepihak yang ternyata keliru karena subjektifitasnya.

Fokus dari pennelitian ini yaitu menganalisis sejauh mana hukum pidana di Indonesia mengakomodir, mengatur dan menanggapi tentang nilai nilai budaya carok dan penerapannya yang bertentangan dengan hukum pidana di Indonesia dimana telah diatur dalam KUHP.

Subjek penelitian ini adalah tentang budaya carok yang di anut oleh masyarakat madura di jawa timur yang sejatinya bertentangan dengan hukum pidana di indonesia. Pengaturan kebudayaan carok madura di Jawa Timur pada hukum pidana dan hukum adat dalam konteks hukum formal di Indonesia. Tindak pidana dalam budaya carok yang di atur dalam KUHP. Fungsi hukum sebagai alat dan mekanisme kontrol sosial. Penegakan nilai dan norma akan budaya carok madura di Jawa Timur. Penyebab atau motif sehingga terjadinya carok pada masyarakat madura di Jawa Timur.

Fokus dari penelitian ini yaitu menganalisis sejauh mana hukum pidana di Indonesia mengakomodir, mengatur dan menanggapi tentang nilai nilai budaya carok dan penerapannya yang bertentangan dengan hukum pidana di Indonesia dimana telah diatur dalam KUHP. Oleh karena itu, permasalahan yang diangkat dalam tulisan ini adalah: bagaimanakah faktor-faktor yang mempengaruhi budaya Carok? Dan bagaimana relasi budaya Carok dengan hukum positif?

\footnotetext{
${ }^{1}$ Dikutip dari https://id.wikipedia.org/wiki/Carok pada pukul 23.24 WIB tanggal 17 September 2017
} 


\section{B. Metode Penelitian}

Dilihat dari jenis budayanya yaitu budaya Carok maka penelitian ini akan menggunakan metode pendekatan komparatif, dengan menggunakan metode pendekatan komparatif bisa mendapatkan alasan atau landasan yang lebih kuat mengenai suatu objek penelitian atau permasalahan, mencatat persamaan antara kedua objek atau lebih dan juga memahami perbedaan yang muncul antara satu objek dengan objek lainnya dan memahami prioritas dan interioritas masing-masing objek serta memperluas wawasan berupa nilai atau informasi mengenai suatu permasalahan dan objek penelitian. Pendekatan ini dimanfaatkan umtuk memandang dan menempatkan manusia dalam sudut pandang lebih luas. Pendekatan ini bisa diterapkan dalam mempelajari kehidupan masyarakat terisolasi maupun tradisi dan adat kebiasaan sosial tertentu.

Data yang digunakan dalam penelitian ini meliputi data primer dan data sekunder. Data primer adalah data penelitian yang diperoleh secara langsung dari sumber aslinya baik secara wawancara, jajak pendapat dari individu atau kelompok, maupun hasil observasi dari suatu obyek, kejadian, atau hasil pengujian. Dalam hal ini, peneliti mengumpulkan data dengan cara memberikan kuisioner atau dengan cara mengamati/observasi.

Data sekunder adalah data penelitian yang diperoleh secara tidak langsung; misalnya melalui buku, catatan, bukti yang telah ada, atau arsip; baik yang dipublikasikan maupun yang tidak dipublikasikan secara umum. Dalam hal ini peneliti mengumpulkan data dengan cara berkunjung ke perpustakaan, pusat kajian, pusat arsip atau membaca banyak buku yang berhubungan. Penelitian ini merupakan penelitian kepustakaan, sehingga data yang diperoleh pun lebih banyak bersumber dari data kepustakaan. Adapun pengumpulan data dilakukan dengan cara menginventarisasi sebanyak mungkin bahan-bahan yang berhubungan dengan kajian penelitian ini melalui buku-buku, jurnal, artikel-artikel, dan internet. Sumber data tersebut diklasifikasikan menjadi dua bagian, yaitu: Data primer yang digunakan sebagai bahan penelitian ini adalah: buku berjudul Carok Konflik Kekerasan dan Harga Diri Orang Madura, karya A. Latief Wiyata dan buku berjudul Manusia Madura, karya Mien Rifai (2007). Data sekunder yang digunakan adalah buku-buku dan hasil penelitian lain yang membahas tentang teori relativisme moral, diantaranya: buku berjudul Etika karangan $\mathrm{K}$. Bertens, buku berjudul Relativisme Etika.

\section{Hasil dan Pembahasan}

\section{Faktor-Faktor yang Mempengaruhi Budaya Carok}

Indonesia dikenal mempunyai budaya yang sangat beragam, namun terkadang tidak semua budaya di Indonesia tersebut dapat dipertahankan seterusnya karena nilai yang terkandung didalamnya seiring waktu sudah tidak sesuai salah satunnya budaya carok. Budaya carok merupakan salah satu budaya yang sudah ada sejak dulu di Madura. Kata carok berasal 
dari bahasa Madura yang berarti "bertarung atas nama kehormatan". Carok merupakan tradisi bertarung yang disebabkan karena alasan tertentu yang berhubungan dengan harga diri yang berhubungan dengan harta, tahta dan wanita ${ }^{2}$, dilakukan dengan menggunakan senjata. Carok merupakan tindakan pembalasan dendam ini dilakukan dengan adu duel (menggunakan senjata celurit) hingga ada korban yang mati, satu lawan satu dan antara lakilaki ${ }^{3}$. Meskipun kadang terjadi carok massal yang mulanya dari individual. ${ }^{4}$

Dari pengertian carok diatas dapat diketahui bahwa munculnya budaya carok ini dikarenakan tidak dapat ditemukan jalan keluar secara damai sehingga harus dengan kekerasan dan apabila ditelaah lebih dalam subjek dari budaya carok ini adalah laki-laki yang melakukan carok dan objeknya adalah jabatan, harta, maupun wanita yang merupakan simbol kekuasaan laki-laki, sehingga dapat dikatakan bahwa carok adalah pertarungan merebutkan kejayaan antara laki laki di Madura. Bagi para pemenang carok merekalah yang mendapatkan kejayaan dan kemasyhuran namun bagi mereka yang kalah hanya mendapat penghinaan saja. Sehingga bukan tidak mungkin budaya carok ini menjadi ajang unjuk gigi dan menjadi jalan pintas. Oleh karena itu dapat dikatakan bahwa ekonomi dan politik menjadi factor dalam budaya carok ini. Apabila dianalogikan, carok merupakan pengadilan dimana patarung merupakan para pihak yang memperjuangkan keadilan dan carok sebagai pengadilan memberikan keadilan itu, kalau dalam pengadilan fakta-fakta lah yang menetukan kemenangan kalau dalam carok kekuatan fisiklah yang menentukan kemenangan.

Budaya carok tidak serta merta terjadi terdapat beberapa syarat yang dillakukan oleh laki laki sebelum bertarung yaitu kadigdajan (latihan bela diri), tamping sereng (meminta jampi jampi kekebalan supranatural), dan banda (kecukupan modal) ${ }^{5}$. Syarat yang harus dilakukan yaitu latihan bela diri merupakan suatu yang wajar ibarat sedia payung sebelum hujan, para laki laki harus melatih diri agar dirinya tidak kalah dalam pertarungan hal itu merupakan suatu yang logis. Untuk syarat kedua adalah meminta jampi jampi kekebalan supranatural, lelaki yang meminta jimat kekebalan tubuh sebenarnya membuktikan kalau pelaku carok takut akan bayang bayang kematian ${ }^{6}$. Syarat ini terdengar tidak logis hal ini menunjukan bahwa masih kentalnya kepercayaan kepercayaan yang ada pada masyarakat Madura berupa animism dan dynamism. Untuk syarat ketiga adalah modal. Yang dimaksud modal adalah modal berapa pun

\footnotetext{
${ }^{2}$ Lontar Madura. "Memahami Tradisi Carok Pada Masyarakat Madura". Diakses dari http://www.lontarmadura.com/tradisi-carok-pada-masyarakat-adat-madura/. Pada tanggal 19 September 2017 pukul 15.03

${ }^{3}$ Tommi. "Tugas Antropologi Budaya: Adat yang Bertentangan dengan Hukum Nasional/Positif". Diakses dari https://tommizhuo.wordpress.com/2014/09/15/tugas-antropologi-budaya-adat-yang-bertentangandengan-hukum-nasionalpositif/. Pada tanggal 19 September 2017 pukul 15.05

${ }^{4}$ Wiyata, Latief. Carok: konflik kekerasan dan harga diri orang Madura.2002.Yogyakarta: LKis Pelangi Aksara. hlm.9

${ }^{5}$ Sumardianta. Simply amazing: inspirasi menyentuh, bergelimang makna. 2009. Jakarta:Gramedia Pustaka Utama. hlm. 149

${ }^{6}$.lbid
} 
tidak jadi masalah, sebab pemenang carok secara sosiologis dan kultural akan mendapat tempat lebih tinggi dibanding sebelumnya ${ }^{7}$. Modal pun merupakan syarat yang dapat diterima akal. Dari ketiga syarat tersebut hanya syarat kedua yang kental dengan unsur kepercayaan masyarakat setempat yang berarti bahwa kepercayaan merupakan salah satu factor yang mempengaruhi budaya carok.

\section{Relasi Budaya Carok dengan Hukum Positif: di 'Persimpangan' Antara}

Adat mempunyai sendiri hukum yang berlaku bagi masyarakat adatnya dan ada hukum adat yang berlaku bagi masyarakat adat yang dikokohkan oleh undang-undang yaitu hak ulayat yang masih diakui sampai sekarang dan mempunyai peraturan sendiri. Hak ulayat ini dikokohkan oleh hukum positif karena nialinya dianggap baik bagi dan masih sesuai dengan perkembangan jaman modern ini, namun tidak untuk budaya carok, nilai dari budaya carok sudah tidak sesuai dengan perkembangan jaman dan dinilai tidak berprikemanusiaan.

Masih melekatnya budaya carok ini menyebabkan adanya perubahan social yang terjadi di Madura dan sekitarnya. Dalam beberapa dasawarsa terakhir carok meningkat dalam lintasan criminal, Madura merupakan tempat kediaman dari sejumlah preman yang beroprasi di Surabaya. ${ }^{8}$ Dikarenakan kekerasan dianggap sebagai suatu hal yang biasa dilakukan. sehingga kekerasan menjadi cara hidup yang telah diterima karena adanya perubahan yang disebabkan oleh kebudayaan yaitu kebudayaan carok tadi. Karena maraknya kekerasan fisik ini sehingga tingkat kriminalitas bertambah dan mau tak mau hukum yang ada harus mampu mengakomodir budaya carok ini.

Budaya carok dapat dikatakan sebagai adu duel bisa satu lawan satu atau kadang kala terjadi keroyokan karena carok masal yang disebutkan diatas. R. Soesilo dalam bukunya yang berjudul Kitab Undang-Undang Hukum Pidana (KUHP) Serta Komentar-Komentarnya Lengkap Pasal Demi Pasal (merujuk pada Penjelasan Pasal 182 KUHP) menjelaskan bahwa undangundang tidak memberikan definisi apa yang dinamakan "berkelahi satu lawan satu" itu. Menurut pengertian umum, lanjut Soesilo, maka "berkelahi satu lawan satu" itu adalah perkelahian dua orang dengan teratur, dengan tantangan lebih dahulu, sedangkan tempat, waktu, senjata yang dipakai, siapa saksi-saksinya ditetapkan pula. Perkelahian ini biasanya disebut "duel". Perkelahian meskipun antara dua orang, apabila tidak memenuhi syarat-syarat tersebut, tidak masuk dalam pasal ini ${ }^{9}$

\footnotetext{
7 Wiyata, Latief. Madura, Carok, dan Polisi ". Diakses dari http://wiyatablog.blogspot.co.id/2008/11/madura-carok-dan-polisi.html. Pada tanggal 19 September 2017 pukul 15.45

Husken, Frans. Orde Zonder Order: Kekerasan dan Dendam di Indonesia 1965 1998.2003.Yogyakarta: LKis Yogyajarta. hlm 238

9 R. Soesilo. Kitab Undang-Undang Hukum Pidana (KUHP): Serta Komentar-Komentarnya Lengkap Pasal Demi Pasal. 1991.Bogor:Politeia Bogor.hlm
} 
Dalam Kitab Undang-Undang Hukum Pidana ("KUHP”), yaitu Bab VI KUHP tentang Perkelahian Satu Lawan Satu. Terkait perkelahian satu lawan satu yang mengakibatkan salah satu terluka, tindakan tersebut dapat dipidana berdasarkan Pasal 184 ayat (2) atau Pasal 184 ayat (3) KUHP (bergantung pada luka yang diakibatkan adalah luka berat atau tidak):

- Pasal 184

(1) Seseorang diancam dengan pidana penjara paling lama sembilan bulan, jika ia dalam perkelahian satu lawan satu itu tidak melukai tubuh pihak lawannya.

(2) Diancam dengan pidana penjara paling lama satu tahun dan empat bulan, barang siapa melukai tubuh lawannya.

(3) Diancam dengan pidana penjara paling lama empat tahun, barang siapa melukai berat tubuh lawannya.

(4) Barang siapa yang merampas nyawa lawannya, diancam dengan pidana penjara paling lama tujuh tahun, atau jika perkelahian satu lawan satu itu dilakukan dengan perjanjian hidup atau mati, diancam dengan pidana penjara paling lama dua belas tahun.

(5) Percobaan perkelahian satu lawan satu tidak dipidana.

Dan dapat apabila diperhatikan dari akibat yang dtimbulkan oleh carok dapat memenuhi unsur unsur yang ada pada pasal lain sebagai berikut:

- Pasal 338 (pembunuhan)

"Barangsiapa dengan sengaja merampas nyawa orang lain, diancam karena pembunuhan dengan pidana penjara paling lama lima belas tahun".

- Pasal 340 (pembunuhan berencana)

"Barangsiapa dengan sengaja dan dengan rencana terlebih dahulu merampas nyawa orang lain, diancam karena pembunuhan dengan rencana, dengan pidana mati atau pidana penjara seumur hidup atau selama waktu tertentu, paling lama dua puluh tahun" .

- Pasal 351 (penganiayaan)

(1) Penganiayaan dipidana dengan pidana penjara selama-lamanya dua tahun delapan bulan atau denda sebanyaknya-banyaknya empat ribu lima ratus ribu rupiah.

(2) Jika perbuatan itu berakibat luka berat, yang bersalah dipidana dengan pidana penjara selama-lamanya lima tahun.

(3) Jika perbuatan itu berakibat matinya orang, maka yang bersalah dipidana dengan pidana penjara selama-lamanya tujuh tahun.

(4) Dengan penganiayaan disamakan merusak kesehatan orang dengan sengaja.

- Pasal 353 (penganiayaan berencana)

(1) Penganiayaan dengan direncanakan lebih dahulu, dipidana dengan pidana penjara selama-lamanya empat tahun. 
(2) Jika perbuatan itu berakibat luka berat, maka yang bersalah dipidana dengan pidana penjara selama-lamanya tujuh tahun.

(3) Jika perbuatan itu berakibat matinya orang, maka yang bersalah dipidana dengan pidana penjara selama-lamanya sembilan tahun.

- Pasal 354 (penganiayaan berat)

(1) Barangsiapa dengan sengaja melukai berat orang lain, dipidana karena penganiayaan berat, dengan pidana penjara selama-lamanya delapan tahun.

(2) Jika perbuatan itu berakibat matinya orang, maka yang bersalah dipidana dengan pidana penjara selama-lamanya sepuluh tahun.

- Pasal 355 (penganiayaan berat berencana)

(1) Penganiayaan berat dengan direncanakan lebih dahulu, dipidana dengan pidana penjara selama-lamanya dua belas tahun.

(2) Jika perbuatan itu berakibat matinya orang, maka yang bersalah dipidana dengan pidana penjara selama-lamanya lima belas tahun.

Pembunuhan, penganiayaan dan penganiayaan berat sama-sama merupakan dampak yang ditimbulkan dari carok karena korbannya bisa luka ringan, luka berat, bahkan meninggal. Namun ajang bergengsi Madura ini juga memenuhi unsur tindak pidana yang di rencanakan karena carok sendiri mempunyai syarat yang harus dipersiapkan sehingga pasal 340, 353, dan 355 KUHP terpenuhi sesuai dengan akibat yang ditimbulkan. Disini dapat dengan jelas dikatakan bahwa budaya arok bertentangan dengan hukum positif yang ada, bahkan tidak hanya di satu pasal yang bisa menjerat budaya carok, karena budaya carok seiring perkembangan jaman dianggap tidak berperikemanusiaan.

\section{Simpulan dan Saran}

\section{Kesimpulan}

a. Carok yang telah dilakukan masyarakat Madura sejak beberapa abad lalu, menggambarkan bahwa orang Madura tidak mampu untuk memilih opsi lain selain kekerasan dalam penyelesaian sengketa. Carok dianggap lebih memenuhi rasa keadilan mereka. Hal yang memengaruhi budaya carok di Madura ini antara lain adalah faktor ekonomi dan politik. Pemerintah masih belum bisa meredam konflik dan memberikan perlindungan terhadap masyarakat dalam aspek keadilan.

b. Budaya carok bila ditinjau dari aspek hukum, jelas bertentangan dengan hukum positif yang berlaku. Carok antara lain dapat dikategorikan dalam Pasal 182, 340, 353, dan 355 Kitab Undang-Undang Hukum Pidana (KUHP). Pada dasarnya harus diperlakukan sama tanpa mengenyampingkam rasa keadilan dalam masyarakat. 


\section{Saran}

a. Cara menyelesaikan suatu sengketa hendaklah tidak menggunakan kekerasan apabila cara damai tidak dapat terealisasikan, seperti budaya Carok. Jangan menjadikan Carok sebagai opsi terakhir dalam penyelesaian sengketa karena budaya ini sudah tidak lagi sesuai pada zaman sekarang.

b. Penerapan suatu hokum adat, sebaiknya tidak bertentangan dengan hokum positif yang berlaku di Indonesia, karena dalam menyelesaikan suatu sengketa harus menjunjung tinggi nilai keadilan dan peri kemanusiaan.

\section{DAFTAR PUSTAKA}

\section{Buku}

Wignjodipuro, Surojo, 1982, Pengantar dan Asas-Asas Hukum Adat, Jakarta: Gunung Agung.

Wiyata, Latief, 2002, Carok: konflik kekerasan dan harga diri orang Madura. Yogyakarta: LKis Pelangi Aksara.

Sumardianta, 2009, Simply amazing: inspirasi menyentuh, bergelimang makna, Jakarta: Gramedia Pustaka Utama.

Husken, Frans, 2003, Orde Zonder Order: Kekerasan dan Dendam di Indonesia 1965 - 1998, Yogyakarta: LKis Yogyakarta.

R. Soesilo, 1991, Kitab Undang-Undang Hukum Pidana (KUHP): Serta Komentar-Komentarnya Lengkap Pasal Demi Pasal, Bogor: Politeia Bogor.

Madura dalam empat jaman: Pedagang, Perkembangan Ekonomi Islam: Suatu Studi Antropologi Ekonomi. Jakarta: Gramedia

\section{Jurnal}

Kurniawan, Joeni Arianto, 2014, Hukum Adat dan Problematika Hukum Indonesia, Perspektif Hukum, Vol. 7 No. 2 November 2007.

Mahrus Ali, Akomodasi Nilai-Nilai Budaya Masyarakat Madura Mengenai Penyelesaian Carok Dalam Hukum Pidana, Jurnal Hukum, Vol. 17, No. 1 Januari 2010.

Erie Hariyanto, Carok VS Hukum Pidana Indonesia (Proses Transformasi Budaya Madura Kedalam Sistem Hukum Indonesia), KARSA, Vol. XII No. 2 Oktober 2007.

Retno Hastijanti, Pengaruh Ritual Carok Terhadap Pemukiman Tradisional Madura, Dimensi Teknik Arsitektur Vol. 33 No. 1, Juli 2005.

Arianto, Henry: Tradisi Carok Pada Masyarakat Madura, 4 September 2012.

E.G Singgih. "Apakah Manusia itu?: Misi gereja dan reapresiasi nilai budaya daerah Madura" Setia: MajalahTeologi No.2 Tahun 1987/1988.

Bustami, Latif. "Carok: Konflik Kekerasan dan Harga diri Orang Madura”. 2002. 


\section{Internet}

https://id.wikipedia.org/wiki/Carok pada pukul 23.24 WIB tanggal 17 September 2017.

Lontar Madura. "Memahami Tradisi Carok Pada Masyarakat Madura". Diakses dari http://www.lontarmadura.com/tradisi-carok-pada-masyarakat-adat-madura/. Pada tanggal 19 September 2017 pukul 15.03.

Tommi. "Tugas Antropologi Budaya: Adat yang Bertentangan dengan Hukum Nasional/Positif". Diakses dari https://tommizhuo.wordpress.com/2014/09/15/tugas-antropologi-budayaadat-yang-bertentangan-dengan-hukum-nasionalpositif/. Pada tanggal 19 September 2017 pukul 15.05.

Wiyata, Latief. "Madura, Carok, dan Polisi". Diakses dari http://wiyatablog.blogspot.co.id/2008/11/madura-carok-dan-polisi.html. Pada tanggal 19 September 2017 pukul 15.45.

Suteja, Amar. "Tradisi Carok di Madura dilihat dari Aspek Sosial dan Moderniasi". Diakses dari http://amarsuteja.blogspot.co.id/2012/10/tradisi-carok-di-madura-dilihat-dari.html. 19 September 2017 pukul 16.15.

Jalal. "Celurit sebagai salah satu simbol tradisi carok pada masyarakat adat Madura: Analisis Semiotik Konotatif Rolan Barther". Diakses dari https://jalal34.wordpress.com/2013/11/26/celurit-sebagai-salah-satu-simbol-tradisi-carokpada-masyarakat-adat-madura-analisis-semiotik-konotatif-rolan-barthes/ .19 September 2017 pukul 16.23 .

"Sejarah Carok". Diakses dari http://www.untukku.com/artikel-untukku/apa-itu-carok-maduradan-bagaimana-sejarahnya-untukku.html. 19 September 2017 pukul 16.23. 